\title{
Reaktywność benzodiazepin a metoda immunoenzymatyczna - problemy interpretacyjne
}

\section{Benzodiazepines' reactivity in immunoassay techniques - problems with interpretation}

\author{
Barbara Potocka-Banaś, Teresa Dembińska ${ }^{凶}$, Krzysztof Borowiak \\ Pomorski Uniwersytet Medyczny w Szczecinie, Katedra Medycyny Sądowej, Zakład Toksykologii Klinicznej i Sądowej, al. Powstańców Wlkp. 72, 70-111 Szczecin \\ $\triangle$ tedemb@pum.edu.pl
}

\begin{abstract}
Introduction: The progress of civilization and the development of pharmaceuticals industry have caused an increase in psychoactive substances abuse. That is why there are often cases of overdose and poisoning with these substances.

Benzodiazepines are among the most commonly used drugs. They are a group of medications producing sedative, anxiolytic, hypnotic, myorelaxant and anticonvulsant effects. Benzodiazepines are a large and diversified group of compounds (over 50 different benzodiazepines are used in clinical treatment), and their metabolites are biologically active. The progress of technology allows the use of more advanced and accurate diagnostic methods. The enzyme multiplied immunoassay technique (EMIT) is a routinely used method in toxicology laboratories, and it is often employed to determine the concentration of benzodiazepines in tested material. This technique is quite easy and quick to perform. However, these advantages have different kinds of consequences, e.g. false-positive
\end{abstract}

results. Therefore, it is important to confirm the results with reference methods.

The aim of this study was to evaluate the reactivity of chosen benzodiazepines using the EMIT ${ }^{\mathrm{R}}$ tox $^{\mathrm{TM}}$ Serum Benzodiazepines Assay. Materials and methods: The precision and accuracy of the results were calculated. Nine benzodiazepines were analyzed (chlordiazepoxide, estazolam, flurazepam, medazepam, nitrazepam, nordazepam, oxazepam, prazepam, and temazepam) using the V-Twin System with EMIT technology from Siemens. Every drug was tested 3 times using different concentrations: $300 \mathrm{ng} / \mathrm{mL}, 1000 \mathrm{ng} / \mathrm{mL}$, and $2000 \mathrm{ng} / \mathrm{mL}$.

Results and conclusions: The EMIT test showed the highest precision for the quantitative determination of prazepam, and the lowest precision for the determination of nitrazepam and medazepam, whereas the test's accuracy was highest for the determination of prazepam, and lowest in the case of nitrazepam. Keywords: benzodiazepines; drug abuse detection; screening; serum analysis; immunoassay.

\begin{abstract}
ABSTRAKT
Wstęp: Postęp cywilizacyjny oraz rozwój przemysłu farmaceutycznego spowodowały wzrost nadużywania środków psychoaktywnych. Dlatego też nierzadko spotyka się przypadki przedawkowania oraz zatruć powyższymi związkami.

Do jednych z najczęściej zażywanych środków psychoaktywnych należą benzodiazepiny. Jest to grupa leków, które wykazują działanie: uspokajająco-nasenne, przeciwlękowe, rozluźniające mięśnie i przeciwdrgawkowe. Benzodiazepiny stanowią dużą i różnorodną grupę związków (ponad 50 różnych benzodiazepin ma zastosowanie kliniczne), a ich metabolity są aktywne biologicznie. Postęp technologiczny umożliwia stosowanie coraz nowszych i dokładniejszych metod diagnostycznych. Rutynowo stosowaną metodą w laboratoriach toksykologicznych jest metoda immunoenzymatyczna (enzyme multiplied immunoassay technique - EMIT). Technika ta charakteryzuje się prostotą wykonania oraz krótkim czasem analizy. Należy jednak pamiętać, że te zalety niosą za sobą różnego rodzaju konsekwencje, np. w postaci wyników fałszywie dodatnich. Dlatego też tak ważne jest potwierdzenie wyniku metodami konfirmacyjnymi. Celem pracy było zbadanie zjawiska reaktywności wybranych benzodiazepin w teście EMIT ${ }^{\mathrm{R}}$ tox $^{\mathrm{TM}}{ }^{\mathrm{M}}$ erum Benzodiazepines Assay.
\end{abstract}

Materiały i metody: Przeprowadzono analizę precyzji i dokładności oznaczeń. Przebadano 9 preparatów benzodiazepin (chlordiazepoksyd, estazolam, flurazepam, medazepam, nitrazepam, nordazepam, oksazepam, prazepam, temazepam) metodą EMIT, przy zastosowaniu analizatora V-Twin firmy Siemens. Każdy lek został oznaczony 3-krotnie przy stężeniach: $300 \mathrm{ng} / \mathrm{mL}$, $1000 \mathrm{ng} / \mathrm{mL}, 2000 \mathrm{ng} / \mathrm{mL}$.

Wyniki i wnioski: Podczas przeprowadzonej analizy immunoenzymatycznej (EMIT) stwierdzono, że najwyższą reaktywność uzyskano podczas oznaczania prazepamu, a najniższą podczas oznaczania nitrazepamu oraz medazepamu. Podkreślić należy, że technika ta nie nadaje się do ilościowego oznaczania oksazepamu i temazepamu. Ważnymi parametrami metod analitycznych jest precyzja i dokładność. Najwyższą precyzję uzyskano podczas oznaczania nitrazepamu, a najniższą podczas oznaczania prazepamu. Natomiast przy wyznaczaniu dokładności pomiaru stwierdzono, że najwyższą dokładność uzyskano podczas oznaczania prazepamu, a najniższą podczas oznaczania nitrazepamu.

Słowa kluczowe: benzodiazepiny; wykrywanie nadużywania leków; testy przesiewowe; badanie surowicy; metoda immunoenzymatyczna. 


\section{WSTEP}

Nadużywanie środków psychoaktywnych prowadzi do poważnych konsekwencji zdrowotnych. Głównym powodem sięgania przez młodzież po tego typu środki jest chęć przeżycia przyjemnych doznań, a także poszukiwanie możliwości wypełnienia wolnego czasu. Dorośli sięgają po środki psychoaktywne, ponieważ nie nadążają za zbyt szybkim tempem życia, co w konsekwencji prowadzi do depresji, lęku czy bezsenności. Rozwój przemysłu farmaceutycznego również przyczynił się do wzrostu zażywania substancji psychoaktywnych, ponieważ umożliwił powstanie nowych preparatów. Ponadto każdego roku obserwuje się wzrost liczby osób zatrutych. Najczęściej odnotowuje się zatrucia środkami uspokajającymi i nasennymi, przede wszystkim z grupy pochodnych benzodiazepiny $[1,2]$.

Budowa chemiczna benzodiazepin oparta jest na szkielecie 1,4-benzodiazepiny. W swojej budowie mają skondensowany pierścień heterocykliczny i benzenowy, w którym w pozycji 7. znajduje się najczęściej chlor. Benzodiazepiny działają poprzez specyficzny dla siebie receptor benzodiazepinowy, który sprzężony jest z receptorem GABA. Leki z tej grupy łączą się z określonym miejscem na receptorze GABA, ale innym niż pozycja dla kwasu $\gamma$-aminomasłowego. W ten sposób poprzez działanie allosteryczne benzodiazepiny nasilają powinowactwo GABA do receptora, co powoduje otwarcie kanału chlorkowego. Następuje zmniejszenie różnicy potencjałów pomiędzy błoną komórkową a wnętrzem komórki. W wyniku tego zdepolaryzowana komórka nerwowa zostaje zablokowana i nie jest w stanie przewodzić impulsów [3].

Większość benzodiazepin podawana jest przede wszystkim doustnie ze względu na bardzo dobre wchłanianie z przewodu pokarmowego. Po wchłonięciu benzodiazepiny silnie wiążą się z białkami osocza, są rozpuszczalne w tłuszczach, przez co ulegają kumulacji w tkance tłuszczowej. Metabolizm benzodiazepin przebiega $\mathrm{w}$ wątrobie, gdzie podlegają takim procesom, jak: hydroksylacja, dezaminacja, demetylacja, dealkilacja, dekarboksylacja, utlenianie czy redukcja i sprzęganie z kwasem glukuronowym. W takim połączeniu wydalane są z moczem [4].

Benzodiazepiny są jednymi z najczęściej przepisywanych i zażywanych leków w Polsce i na świecie. Swoim działaniem obejmują wiele obszarów mózgu, dzięki czemu wykazują działanie nie tylko uspokajająco-nasenne, ale również: przeciwlękowe (kora mózgu), rozluźniające mięśnie (rdzeń kręgowy) i przeciwdrgawkowe (pień mózgu). Z powodu tak szerokich możliwości ich stosowania wynikają następujące problemy: nadużycie, niewłaściwe zażywanie czy ułatwienie przestępstw kryminalnych. Najczęściej notowanymi działaniami niepożądanymi są splątanie, senność, zaburzona koordynacja, amnezja, osłabienie siły mięśniowej [5].

Objawy przedawkowania benzodiazepin to m.in.: senność, splątanie, ataksja, hipotonia, zaburzenia oddychania, śpiączka. Szczególnie niebezpieczne są zatrucia mieszane, zwłaszcza gdy jednocześnie zażyto inne środki działające depresyjnie na ośrodkowy układ nerwowy, np. alkohol etylowy. Obserwuje się wówczas zjawisko synergizmu addytywnego [6].
Biorąc pod uwagę ogromną liczbę substancji powodujących zatrucia oraz fakt, iż zazwyczaj informacje co do rodzaju przyjętego środka są ograniczone, kluczową rolę w podjęciu właściwych działań lekarskich odgrywa wynik pełnej analizy toksykologicznej $[7,8]$. Analiza toksykologiczna jest trudnym i wieloetapowym procesem, którego celem jest identyfikacja oraz ilościowe oznaczenie poszukiwanych substancji w możliwie jak najkrótszym czasie. Stosowane metody muszą być swoiste i czułe. W laboratoriach toksykologicznych standardowo stosowanymi metodami analitycznymi są metody immunologiczne i chromatograficzne $[8,9,10]$. Do metod immunologicznych zaliczane są metoda immunoenzymatyczna (enzyme multiplied immunoassay technique - EMIT) i metoda immunofluorescencji w świetle spolaryzowanym (fluorescence polarization immunoassay - FPIA). Metody te pozwalają na określenie stężenia wybranych substancji. Zasada metody EMIT polega na współzawodnictwie o miejsce wiązania przeciwciał pomiędzy substancją w próbce a substancją oznakowaną enzymem dehydrogenazą glukozo-6-fosforanową (G-6-PDH). Aktywność enzymu obniża się w wyniku wiązania z przeciwciałem, tak więc stężenie leku w próbce można określić, mierząc aktywność enzymu. Aktywny enzym przekształca NAD do NADH, co powoduje zmianę absorbancji, którą można mierzyć spektrofotometrycznie.

Podstawową zaletą metod immunologicznych jest brak konieczności izolacji oznaczanych substancji z materiału biologicznego, co skutkuje uzyskaniem wyniku w krótkim czasie. Zaletą jest również wysoka czułość, prostota wykonania oznaczenia oraz możliwość przeprowadzenia analizy nawet w przypadku bardzo małej objętości materiału biologicznego. Wadą tych metod jest wysoki koszt odczynników, jak również niespecyficzność reakcji w obrębie danej grupy farmakologicznej. Nie każdy związek w obrębie swojej grupy farmakologicznej reaguje z taką samą wydajnością, co może doprowadzić do otrzymania wyników fałszywie ujemnych. Dlatego też wyznaczenie reaktywności poszczególnych pochodnych benzodiazepiny pozawala na określenie przydatności klinicznej zastosowanego testu immunologicznego. Kolejnym problemem, który może pojawić się podczas analizy, jest zjawisko reaktywności krzyżowej. Związki pochodzące z innej grupy farmakologicznej, lecz podobne budową do poszukiwanej substancji, mogą dawać wyniki fałszywie dodatnie. Producenci testów podają substancje oraz zakresy ich stężeń, które mogą wpłynąć na wynik badania $[10,11,12]$.

Mając na uwadze ograniczenia metod immunologicznych, wyniki uzyskiwane podczas analizy tymi metodami powinny być weryfikowane metodami konfirmacyjnymi. Do metod konfirmacyjnych stosowanych w analizie toksykologicznej należą metody chromatograficzne, takie jak wysokosprawna chromatografia cieczowa z detektorem diodowym (HPLC/DAD) czy chromatografia cieczowa sprzężona ze spektrometrem mas (LC/MS). Metody chromatograficzne charakteryzują się bardzo dużą specyficznością, pozwalającą na dokładne określenie rodzaju przyjętych substancji, wysoką czułość umożliwiającą detekcję i oznaczenie ilościowe niskich stężeń substancji. Podstawową wadą metod 
chromatograficznych jest czasochłonność, ponieważ zawsze wymagają etapu izolacji (ekstrakcja ciecz-ciecz, ekstrakcja ciecz-ciało stałe) poszukiwanych substancji z matrycy biologicznej. Ponadto aparaty HPLC, LC/MS są bardzo kosztowne, co ogranicza ich zastosowanie w rutynowych laboratoriach diagnostycznych [9].

Podkreślić należy, że metody konfirmacyjne typu HPLC, LC/MS są przede wszystkim metodami jakościowymi i ilościowymi. Jednak oznaczeń ilościowych można dokonać po wcześniejszej walidacji metody do oznaczania określonych związków, np. można ilościowo oznaczyć każdą pochodną benzodiazepiny. Proces ten jest jednak bardzo pracochłonny i wymaga dużych nakładów finansowych. Wydaje się, że można byłoby zaoszczędzić czas, jak również obniżyć koszty, gdyby w metodach immunologicznych opracować reaktywność poszczególnych benzodiazepin w teście stosowanym do oznaczenia grupowego. Jednak w praktyce przeliczniki reaktywności można wykorzystać tylko wówczas, gdyby określona benzodiazepina została zidentyfikowana metodą HPLC, LC/MS, a następnie oznaczona ilościowo metodą immunologiczną, z uwzględnieniem znajomości reaktywności wykrytej benzodiazepiny w tym teście.

Ze względu na problemy występujące podczas analizy benzodiazepin metodą immunoenzymatyczną w pracy podjęto próbę wyznaczenia reaktywności wybranych benzodiazepin w teście do oznaczenia tej grupy leków. Podjęto również próbę wyznaczenia precyzji i dokładności pomiarów.

\section{MATERIAŁY I METODY}

Do badań wybrano następujące substancje: chlordiazepoksyd, medazepam, nitrazepam, nordazepam, oksazepam, prazepam, temazepam, estazolam, flurazepam. Wzorce substancji $\mathrm{w}$ formie liofilizowanej zostały zakupione od firmy Polfarma. Roztwory wzorcowe o stężeniu $1 \mathrm{mg} / \mathrm{mL}$ uzyskano poprzez rozpuszczenie odpowiednio odważonej ilości substancji. Następnie przygotowano roztwory robocze przez 10-krotne rozcieńczenie roztworów wzorcowych, uzyskując stężenie końcowe $100 \mu \mathrm{g} / \mathrm{mL}$ (roztwór roboczy).

Materiałem biologicznym użytym do badań była surowica krwi ludzkiej zabezpieczona po badaniach toksykologicznych w Zakładzie Toksykologii Klinicznej i Sądowej Pomorskiego Uniwersytetu Medycznego w Szczecinie, które w badaniu na obecność leków z grupy benzodiazepin dały wynik ujemny. Materiał biologiczny badany był metodami konfirmacyjnymi - wysokosprawną chromatografią cieczową z detektorem diodowym lub chromatografią cieczową sprzężoną ze spektrometrem mas.

Próbki badane uzyskano przez obciążenie surowicy odpowiednią objętością roztworu roboczego, uzyskując stężenia końcowe 300, 1000, 2000 ng/mL substancji badanej. Dla każdej substancji przygotowano:

- 3 próby o stężeniu $300 \mathrm{ng} / \mathrm{mL}$ : do $997 \mu \mathrm{L}$ surowicy dodano $3 \mu \mathrm{L}$ wzorca roboczego;

- 3 próby o stężeniu $1000 \mathrm{ng} / \mathrm{mL}$ : do $990 \mu \mathrm{L}$ surowicy dodano $10 \mu \mathrm{L}$ wzorca roboczego;
- 3 próby o stężeniu $2000 \mathrm{ng} / \mathrm{mL}$ : do $980 \mu \mathrm{L}$ surowicy dodano $20 \mu \mathrm{L}$ wzorca roboczego.

Dodatkowo dla medazepamu, oksazepamu oraz temazepamu przygotowano próbki o stężeniu $5000 \mathrm{ng} / \mathrm{mL}$.

Reaktywności wybranych benzodiazepin wyznaczono dla metody EMIT, wykorzystując aparat V-Twin firmy Siemens. Komercyjny test do oznaczeń benzodiazepin został opracowany dla diazepamu przez firmę Siemens - EMITRtoxTMSerum Benzodiazepines Assay. Razem z odczynnikami zostały zakupione kalibratory dedykowane do testu. Krzywa kalibracyjna dla diazepamu została wyznaczona w zakresie 0,0-2000 ng/mL, natomiast granica „cut-off” zadeklarowana przez producenta testu wynosiła $70 \mathrm{ng} / \mathrm{mL}$.

Wynik reaktywności wyliczono z następującego wzoru:

$$
\text { Reaktywność }=\mathrm{C}_{\mathrm{sr}} / \mathrm{C}_{\mathrm{rz}} \times 100 \% \text {, }
$$

gdzie: $\mathrm{C}_{\mathrm{sr}}$ - średnia wartość stężenia oznaczonego, $\mathrm{C}_{\mathrm{rz}}$ - wartość stężenia rzeczywistego.

Precyzja została określona na podstawie odchylenia standardowego.

Za miarę dokładności przyjęto błąd względny pomiarów i obliczono wg wzoru:

$$
\mathrm{B}_{\mathrm{wz}}=\mathrm{C}_{\mathrm{rz}}-\mathrm{C}_{\mathrm{sr}} / \mathrm{C}_{\mathrm{rz}} \times 100 \% \text {, }
$$

gdzie: $\mathrm{C}_{\mathrm{rz}}$ - stężenie rzeczywiste próbki, $\mathrm{C}_{\mathrm{sr}}$ - średnie stężenie oznaczone.

\section{WYNIKI}

Oznaczone wartości stężeń badanych próbek uzyskano podczas analizy przeprowadzonej aparatem V-Twin firmy Siemens. W tabeli 1 przedstawiono wyniki reaktywności, jakie uzyskano dla poszczególnych leków. W przypadku wyniku poniżej 70 ng/mL (wartość „cut off” metody) dodatkowo wykonywano analizę stężenia $5000 \mathrm{ng} / \mathrm{mL}$ badanego związku. W przypadku próbki badanej prazepamu o stężeniu $2000 \mathrm{ng} / \mathrm{mL}$ wyniki uzyskano po 2-krotnym rozcieńczenia próbki (wyniki pierwszych pomiarów powyżej $2000 \mathrm{ng} / \mathrm{mL}$ ), a następnie przeliczeniu uzyskanego wyniku (przemnożeniu ×2).

\section{DYSKUSJA}

Metody immunologiczne umożliwiają szybkie określenie stężenia substancji psychoaktywnych w przypadku zatruć [8]. W pracy podjęto próbę wyznaczenia reaktywności pochodnych benzodiazepiny (chlordiazepoksyd, medazepam, nitrazepam, nordazepam, oksazepam, prazepam, temazepam, estazolam, flurazepam) w teście do oznaczania benzodiazepiny, którego parametry wyznaczono przy użyciu diazepamu, podczas analizy metodą immunoenzymatyczną, używając aparatu V-Twin firmy Siemens.

Podczas oznaczania reaktywności przy stężeniu $300 \mathrm{ng} / \mathrm{mL}$ najwyższą reaktywność wykazał prazepam - 93,02\%, natomiast najniższą chlordiazepoksyd -36,10\%. Reaktywność 
TABELA 1. Wyniki reaktywności, precyzji i dokładności pomiarów dla badanych leków

\begin{tabular}{|c|c|c|c|c|c|}
\hline & $\begin{array}{c}C_{r z} \\
\text { (ng/mL) }\end{array}$ & $\begin{array}{c}C_{s i r} \\
(n g / m L)\end{array}$ & $\begin{array}{c}\text { Reaktywność } \\
(\%)\end{array}$ & SD & $\begin{array}{l}\mathrm{B}_{\mathrm{wz}} \\
(\%)\end{array}$ \\
\hline \multirow[t]{3}{*}{ Chlordiazepoksyd } & 300 & 108,30 & 36,10 & 21,57 & 63,90 \\
\hline & 1000 & 218,40 & 21,84 & 33,26 & 78,16 \\
\hline & 2000 & 282,20 & 14,11 & 44,43 & 85,89 \\
\hline \multirow[t]{3}{*}{ Estazolam } & 300 & 126,77 & 42,26 & 3,93 & 57,74 \\
\hline & 1000 & 267,07 & 26,71 & 14,34 & 73,29 \\
\hline & 2000 & 501,23 & 25,06 & 21,57 & 74,94 \\
\hline \multirow[t]{3}{*}{ Flurazepam } & 300 & 188,04 & 62,68 & 1,81 & 37,32 \\
\hline & 1000 & 389,80 & 38,98 & 20,59 & 61,02 \\
\hline & 2000 & 607,60 & 30,38 & 23,85 & 69,62 \\
\hline \multirow[t]{3}{*}{ Medazepam } & 300 & $<70$ & - & - & - \\
\hline & 1000 & $<70$ & - & - & - \\
\hline & 5000 & 110,00 & 2,20 & & \\
\hline \multirow[t]{3}{*}{ Nitrazepam } & 300 & $<70$ & - & - & - \\
\hline & 1000 & 119,90 & 11,99 & 6,24 & 88,00 \\
\hline & 2000 & 182,03 & 9,10 & 15,29 & 90,90 \\
\hline \multirow[t]{3}{*}{ Nordazepam } & 300 & 208,63 & 69,54 & 1,65 & 30,46 \\
\hline & 1000 & 544,57 & 54,46 & 205,46 & 45,54 \\
\hline & 2000 & 807,90 & 40,40 & 41,31 & 59,61 \\
\hline \multirow[t]{4}{*}{ Oksazepam } & 300 & $<70$ & - & - & - \\
\hline & 1000 & $<70$ & - & - & - \\
\hline & 2000 & $<70$ & - & - & - \\
\hline & 5000 & $<70$ & - & - & - \\
\hline \multirow[t]{2}{*}{ Prazepam } & 300 & 279,07 & 93,02 & 6,71 & 6,98 \\
\hline & 2000 & 2201,47 & 110,07 & 243,58 & 10,07 \\
\hline \multirow[t]{4}{*}{ Temazepam } & 300 & $<70$ & - & - & - \\
\hline & 1000 & $<70$ & - & - & - \\
\hline & 2000 & $<70$ & - & - & - \\
\hline & 5000 & $<70$ & - & - & - \\
\hline
\end{tabular}

$\mathrm{C}_{\mathrm{rz}}$ - wartość stężenia rzeczywistego; $\mathrm{C}_{\mathrm{sr}}$ - średnia wartość stężenia oznaczonego; SD - odchylenie standardowe; $\mathrm{B}_{\mathrm{wz}}$ - błąd względny

pozostałych beznodiazepin wynosiła odpowiednio: nordazepam - 69,54\%, flurazepam - 62,68\%, estazolam - 42,26\%. Przy stężeniu na poziomie $300 \mathrm{ng} / \mathrm{mL}$ nie uzyskano odpowiedzi ze strony: medazepamu, nitrazepamu, oksazepamu, temazepamu.

Podczas oznaczania reaktywności przy stężeniu $1000 \mathrm{ng} / \mathrm{mL}$ najwyższą reaktywność wykazał prazepam - 100,16\%, a najniższą nitrazepam - 11,99\%. Reaktywność pozostałych pochodnych benzodiazepiny przedstawiała się następująco: nordazepam - 54,46\%, flurazepam - 38,98\%, estazolam - 26,71\%, chlordiazepoksyd -21,84\%. Pomimo zwiększenia stężenia nadal nie uzyskano odpowiedzi ze strony medazepamu, oksazepamu oraz temazepamu.

Jako najwyższe oznaczane stężenie przyjęto $2000 \mathrm{ng} / \mathrm{mL}$. Najwyższą reaktywność wykazał ponownie prazepam $100,07 \%$, a najniższą nitrazepam -11,99\%. Reaktywność pozostałych pochodnych benzodiazepiny przedstawiała się następująco: nordazepam - 40,40\%, flurazepam - 30,38\%, estazolam-25,06\%, chlordiazepoksyd -14,11\%. Zaobserwowano, że w przypadku medazepamu, oksazepamu oraz temazepamu nadal nie uzyskano odpowiedzi.

Aby określić reaktywność medazepamu, oksazepamu i temazepamu, przygotowano próbki o stężeniu $5000 \mathrm{ng} / \mathrm{mL}$. Wynik dodatni uzyskano tylko dla medazepamu, który wynosił $110 \mathrm{ng} / \mathrm{mL}$ (reaktywność na poziomie 2,20\%). Podkreślić należy, iż mimo wzrostu stężenia oznaczanych benzodiazepin reaktywność chlordiazepoksydu, estazolamu, flurazepamu, nitrazepamu i nordazepamu malała, z wyjątkiem prazepamu, którego reaktywność wzrastała.

Na podstawie uzyskanych wyników w metodzie EMIT stwierdzono, że najniższą reaktywność krzyżową wykazywał nitrazepam i chlordiazepoksyd, a najwyższą prazepam oraz nordazepam. Podobnie wysoki poziom reaktywności dla prazepamu uzyskali Huang i Moodyt. Średnia reaktywność w ich badaniach przy użyciu techniki immunoenzymatycznej wynosiła dla prazepamu 112,65\%. Zaskakujący był uzyskany przez nich wynik dla medazepamu, którego średnia reaktywność wynosiła 74,55\%. W przeprowadzonych badaniach 
własnych wynik reaktywności dla medazepamu wyniósł zaledwie 2,20\%. Równie wysoki procent uzyskali dla chlordiazepoksydu $-67,80 \%$ oraz nitrazepamu $-79,55 \%$ w porównaniu do otrzymanych wyników własnych, odpowiednio 24,02\% oraz $10,55 \%$ [12].

Huang i wsp. uzyskali wysoki średni procent reaktywności dla nordazepamu, który wyniósł 100,88\%. Jest on wyższy w porównaniu z wynikami uzyskanymi podczas prowadzonych badań. Tak wysoki poziom reaktywności osiągnięty dla prazepamu może wynikać z faktu, iż jego budowa jest w największym stopniu zbliżona do budowy diazepamu, który firma Siemens zastosowała do opracowania parametrów metody EMIT w teście do oznaczania benzodiazepin. Fakt ten tłumaczy również wysoki wynik dla nordazepamu. Natomiast nitrazepam oraz chlordiazepoksyd wykazują najmniejsze podobieństwo strukturalne $\mathrm{z}$ analizowanych benzodiazepin do diazepamu. W ich strukturze pojawiają się dodatkowe atomy azotu, które mogą w znaczący sposób wpływać na obniżoną wartość reaktywności tych związków [13, 14].

Kolejnym etapem pracy była ocena precyzji i dokładności pomiarów oraz przygotowanie próbek. Precyzja określa rozrzut wartości mierzonych w efekcie stosowania metody analitycznej. Z uwagi na warunki ustalania precyzji metody analitycznej można wyróżnić dodatkowe kryterium, czyli powtarzalność - analizę wykonuje ten sam analityk, na tym samym aparacie, korzystając z tych samych odczynników w krótkich odstępach czasu. Natomiast dokładność określa zgodność wyników uzyskiwanych dzięki stosowanej metodzie analitycznej z wartością przyjętą jako prawdziwa.

Z przeprowadzonych badań oraz wyliczeń wynika, iż wraz ze wzrostem stężeń przygotowywanych i oznaczanych próbek wzrastała wartość precyzji, czyli rozrzut wyników wokół średniej był coraz większy. Najlepszą precyzję przy stężeniu $300 \mathrm{ng} / \mathrm{mL}$ otrzymano przy oznaczeniu nordazepamu $(1,65)$ i flurazepamu $(1,81)$, najgorszą natomiast przy oznaczeniu chlordiazepoksydu $(21,57)$. Przy stężeniu $1000 \mathrm{ng} / \mathrm{mL}$ najlepszą precyzję uzyskano dla nitrazepamu $(6,24)$, a najgorszą dla prazepamu $(42,71)$. Przy stężeniu $2000 \mathrm{ng} / \mathrm{mL}$ najlepszą precyzję osiągnięto dla nitrazepamu $(15,29)$, a najgorszą dla prazepamu $(243,58)$.

Na podstawie wyników i obliczeń można stwierdzić, iż wraz ze wzrostem stężenia oznaczanej pochodnej benzodiazepiny wzrastała wartość dokładności, czyli średnie wyniki oznaczeń były coraz bardziej oddalone do wartości rzeczywistej. Najlepszy procent dokładności przy stężeniu $300 \mathrm{ng} / \mathrm{mL}$ zaobserwowano dla prazepamu $(6,98 \%)$, najgorszy dla chlordiazepoksydu (63,90\%). Przy stężeniu $1000 \mathrm{ng} / \mathrm{mL}$ pomiar prazepamu $(0,16 \%)$ okazał się najbardziej dokładny, natomiast najmniej dokładny dla nitrazepamu (88,00\%). Dla stężenia $2000 \mathrm{ng} / \mathrm{mL}$ dokładność podczas oznaczenia prazepamu wyniosła 10,07\%, a nitrazepamu 90,90\%.

Biorąc pod uwagę uzyskane rezultaty, należy rozważyć możliwość indywidualnego ustalania procentu reaktywności w metodzie EMIT w danym laboratorium z uwagi na znaczną rozbieżność otrzymanych wyników z informacjami podanymi przez producenta testu, jak również danymi dostępnymi w piśmiennictwie. Podkreślić należy, że znajomość reaktywności poszczególnych benzodiazepin w teście grupowym można wykorzystać tylko w przypadku wcześniejszej identyfikacji danego związku metodą konfirmacyjną, taką jak HPLC czy LC/MS.

\section{WNIOSKI}

1. Metoda immunoenzymatyczna może być wykorzystana do analizy ilościowej wybranych pochodnych benzodiazepiny po wcześniejszej identyfikacji metodą konfirmacyjną i wyznaczeniu reaktywności krzyżowej w laboratorium.

2. Metoda immunoenzymatyczna nie może być stosowana do analizy ilościowej oksazepamu i temazepamu z uwagi na brak odpowiedzi ze strony przeciwciał.

3. Najwyższą precyzję uzyskano podczas oznaczania nitrazepamu, a najniższą podczas oznaczania prazepamu. Natomiast najwyższą dokładność uzyskano podczas oznaczania prazepamu, a najniższą podczas oznaczania nitrazepamu.

\section{PIŚMIENNICTWO}

1. Kolbarska A. Konsumpcja substancji psychoaktywnych przez młodzież szkolną. Poradnia internetowa dla osób zagrożonych uzależnieniem od narkotyków, uzależnionych i ich bliskich. Narkomania.org.pl; 2013. http://www.narkomania.org.pl/czytelnia/konsumpcja-substancjipsychoaktywnych-przez-mlodziez-szkolna (5.03.2014).

2. Sierosławski J. Problem narkotyków i narkomanii w Polsce. Rozmiary i trendy zjawiska. Narkomania.org.pl; 2015. http://www.narkomania. org.pl/czytelnia/problem-narkotykow-narkomanii-polsce-rozmiarytrendy-zjawiska (5.03.2014).

3. Lader M. Benzodiazepines revisited - will we ever learn? Addiction 2011;106:2086-109.

4. Kostowski W. Farmakologia. Podstawy farmakoterapii. Podręcznik dla studentów medycyny i lekarzy. Tom 2. 3rd ed. Warszawa: Wydawnictwo Medyczne; 2003. p. 93-101.

5. Tan KR, Brown M, Labouèbe G, Yvon C, Creton C, Fritschy JM, et al. Neural bases for addictive properties of benzodiazepines. Nature 2010;463:769-74.

6. Brandys J. Toksykologia - wybrane zagadnienia. Kraków: Wydawnictwo Uniwersytetu Jagiellońskiego; 1999. p. 34-66.

7. Adamowicz P. Analiza toksykologiczna w sprawach o ułatwienie dokonania zgwałcenia przez podanie środka farmakologicznego. Probl Krym 2005;248:26-30.

8. Adamowicz P, Kała M. Simultaneous screening for and determination of 128 date-rape drugs in urine by gas chromatography-electron ionizationmass spectrometry. Forensic Sci Int 2010;198:39-45.

9. Kała M. Problemy toksykologa analityka w dobie technik sprzężonych. Problems Forensic Sci 2008;75:228-46.

10. Wachowiak R. Ocena toksykologiczna metod diagnostycznych stosowanych w zatruciach środkami psychoaktywnymi. Przegl Lek 2001;58:215-9.

11. Pesce AJ, Mikel C, Rosenthal M, West C. Therapeutic monitoring of benzodiazepines in the management of pain: Current limitations of point of care immunoassays suggest testing by mass spectrometry to assure accuracy and improve patient safety. Clin Chim Acta 2012;413:1199-202.

12. Huang W, Moodyt DE. Immunoassay detection of benzodiazepines and benzodiazepine metabolites in blood. J Anal Toxicol 1995;19:333-42.

13. Huang W, Moodyt DE, Andrenyak DM, Rollins DE. Immunoassay detection of nordiazepam, triazolam, lorazepam, and alprazolam in blood. J Anal Toxicol 1993;17:365-9.

14. Bertol E, Vaiano F, Furlanetto S, Mari F. Cross-reactivities and structure reactivity realtionships of six benzodiazepines to EMIT immunoassay. J Pharm Biomed Anal 2013;84:168-72. 


\section{KOMENTARZ}

Benzodiazepiny (BDA) należą do grupy często nadużywanych leków, dlatego ich oznaczanie w materiale biologicznym stanowi ważne zagadnienie praktyczne w codziennej analizie toksykologicznej. Ma ona na celu wykrycie, identyfikację oraz ilościowe oznaczanie poszukiwanych substancji lub ich metabolitów i jest niezbędnym elementem diagnostyki ostrych zatruć, leczenia uzależnień i opiniowania sądowo-lekarskiego. Z tego względu zasadne i przynoszące wymierne korzyści są wszelkie próby oceny jakości analizy toksykologicznej. Jedną z metod oznaczania BDA jest półilościowa metoda immunoenzymatyczna (EMIT). Powszechnie wiadomo, że podczas jej stosowania należy uwzględnić wpływ tła biologicznego, różną reaktywność poszczególnych preparatów oraz możliwość reaktywności krzyżowej.

Artykuł w zasadzie nie zawiera elementów nowości naukowej, ale posiada niewątpliwy walor praktyczny. Bardzo przydatne wydaje się porównywanie różnych możliwych metod oznaczania leków w materiale biologicznym ze zwróceniem uwagi na ich zalety i wady oraz możliwość wykorzystania w codziennej praktyce klinicznej. Dyskusja na temat problemów interpretacji uzyskanych wyników zawsze budzi zainteresowanie toksykologów klinicznych.

dr hab. n. med., prof. PUM Anna Machoy-Mokrzyńska

\section{KOMENTARZ}

Diagnostyka laboratoryjna środków psychoaktywnych w Polsce należy do najsłabszych ogniw w systemie działań zmierzających do ograniczenia narkomanii, co wynika głównie z braku nowoczesnego zaplecza aparaturowego. W konsekwencji nie ma możliwości szybkiej i wiarygodnej identyfikacji przyjętych środków uzależniających. Obecnie w laboratoriach analitycznych do diagnostyki pacjentów z objawami zatrucia substancjami psychoaktywnymi, a także do monitorowania terapii czy w ocenie abstynencji powszechnie wykorzystywane są testy immunochemiczne. Testy te należą do badań diagnostycznych, które mogą być wykonane praktycznie w każdym laboratorium analitycznym z uwagi na ich prostotę, niski koszt oznaczenia, krótki czas oczekiwania na wynik, a przede wszystkim brak konieczności posiadania drogiej aparatury. Pomimo wielu zalet metody te nie gwarantują jednak stuprocentowej wiarygodności uzyskanych wyników, ponadto są mało specyficzne, co może skutkować uzyskaniem wyników fałszywie pozytywnych lub fałszywie negatywnych. Istnieje wiele prac, w których opisano ograniczenia związane ze stosowaniem testów immunochemicznych i interpretację uzyskanych wyników. Autorzy tych publikacji podkreślają, że wyniki fałszywe testów wynikają z ograniczonej specyficzności metod immunoenzymatycznych, a także obecności substancji interferujących, takich jak: leki, używki, suplementy diety. Testy immunochemiczne zaliczane są do metod przesiewowych. Dodatni wynik badania przesiewowego oznacza jedynie obecność w materiale biologicznym związków z danej grupy narkotyków, a uzyskane wyniki tych testów powinny być potwierdzone w specjalistycznych laboratoriach toksykologicznych metodami referencyjnymi - chromatografii gazowej lub cieczowej z różnymi systemami detekcji (HPTLC, GC, HPLC), czy też technik łączonych (GC/MS, GC/FTIR, LC/MS, HPLC-ESI-MS-MS) umożliwiających pełną identyfikację i analizę składników mieszaniny.

Autorzy publikowanego artykułu zakładają, że znajomość reaktywności poszczególnych benzodiazepin w teście stosowanym do oznaczenia grupowego pozwoli na zmniejszenie kosztów analizy. Niemniej podkreślają, że przeliczniki reaktywności mogą być wykorzystane po wcześniejszej identyfikacji benzodiazepiny metodą konfirmacyjną. Bardziej właściwe byłoby określenie celu jako badania reaktywności wybranych benzodiazepin w kontekście wpływu na wynik testu immunochemicznego wystandaryzowanego na diazepam. Możliwość uzyskania fałszy wych wyników, zarówno negatywnych, jak i pozytywnych, w teście przesiewowym EMIT dla benzodiazepin może być przyczyną poważnych konsekwencji zarówno terapeutycznych, jak i prawnych.

prof. dr hab. Barbara Zielińska-Psuja

\section{ODPOWIEDŹ AUTORÓW}

W laboratoriach analitycznych rutynowo stosowanymi metodami są metody immunoenzymatyczne. Natomiast metody konfirmacyjne, takie jak wysokosprawna chromatografia cieczowa (HPLC) czy chromatografia cieczowa sprzężona ze spektrometrem mas (LC/MS), są wykorzystywane w laboratoriach specjalistycznych (np. toksykologicznych). Oczywiście, jak słusznie podkreślił Komentator, nie ma sensu identyfikacja i oznaczanie ilościowe pochodnych benzodiazepiny np. metodą LC/MS, a następnie powrót do metody immunologicznej (np. EMIT) w celu oznaczenia ilościowego określonej pochodnej. Jednak z uwagi na ograniczony dostęp do specjalistycznej aparatury LC/MS, należy rozważyć wyznaczenie reaktywności krzyżowej pochodnych benzodiazepiny w metodzie immunoenzymatycznej w danym laboratorium. Podkreślić należy, że w województwie zachodniopomorskim (Szczecin) pracuje tylko jedno laboratorium wykonujące analizę jakościowo-ilościową pochodnych benzodiazepiny. Natomiast ilość laboratoriów analitycznych jest znacznie większa, gdyż praktycznie występują one przy każdym szpitalu na terenie całego województwa zachodniopomorskiego. W przypadku diagnostyki pacjenta (np. ze Świnoujścia) zatrutego określoną pochodną benzodiazepiny w jednostce specjalistycznej (laboratorium toksykologiczne w Szczecinie), badanie kontrolne poziomu leku mogłoby być wykonane w laboratorium analitycznym w Świnoujściu, jeżeli takie laboratorium dysponowałoby aparatem immunoenzymatycznym i miałoby wyznaczone reaktywności dla poszczególnych pochodnych benzodiazepiny. A więc w takim przypadku jest seans powrotu do metod immunologicznych. Podkreślić należy aspekt ekonomiczny transportu materiału biologicznego ze szpitala z terenu województwa zachodniopomiorskiego do Szczecina. Materiał biologiczny podczas transportu musi mieć zapewnione specjalne warunki, a to zawiązane jest z kosztami. 